\title{
IN VITRO AND FIELD PERFORMANCE OF SOME SEED TREATING FUNGICIDAL GROUPS ON GERMINATION, DISEASE INCIDENCE AND YIELD CONTRIBUTING CHARACTERS OF CHICKPEA (BARI Chola-10)
}

\author{
Md. Shahriar kobira, Md. Hafijur Rahmana, Pradip Hajonga, Md. Harun-Or-Rashid ${ }^{b}$ \\ aScientific officer, Bangladesh Agricultural Research Institute, Bangladesh. \\ ${ }^{b}$ Agricultural Development Officer, International Maize and Wheat Improvement Center (CIMMYT), Bangladesh Office. \\ *Corresponding author Email: shahriar1302027@gmail.com
}

This is an open access article distributed under the Creative Commons Attribution License CC BY 4.0, which permits unrestricted use, distribution, and reproduction in any medium, provided the original work is properly cited.

\section{ARTICLE DETAILS}

\section{Article History:}

Received 06 August 2020 Accepted 09 September 2020

Available online 05 October 2020

\begin{abstract}
Low productivity of chickpea in Bangladesh is obtained due to different disease incidence and seed treatment by fungicides can minimize the disease severity. A laboratory and field experiment was conducted at Regional Agricultural Research Station, Jashore, Bangladesh to evaluate the effect of some seed treating fungicidal groups on germination, soil-borne as well as seed-borne disease incidence and yield contributing characters of chickpea (BARI Chola-10). In laboratory the experiment was conducted in CR design and in field condition the experiment was conducted in RCB design with three replications in both conditions. Five fungicides namely Provax 200 WP (Carboxin +Thiram), Secure 600 WG (Fenamidone + Mancozeb), Rovral 50 WP (Iprodione), Bavistin 50 WP (Carbendazim), Captan 50 WP along with control was maintained as experimental treatment. The fungicidal group treatments showed significant variation among the parameters except days to mature. The highest germination (92\%), plumule length $(31.22 \mathrm{~mm})$, radicle length $(12.26$ $\mathrm{mm}$ ), Vigor index (4015.5), Percent disease reduction over control (84\%), plant height (63.67 cm), plants m2 (31), pods plant ${ }^{-1}(81)$, grain yield (2062.7 kg ha-1) and the lowest days to $50 \%$ flowering (65), disease incidence $(3.33 \%)$ was found when seeds were treated with fungicide Provax 200 WP (Carboxin +Thiram). To reduce the soil-borne as well as seed-borne disease incidence and to increase grain yield of chickpea, seed treatment with provax 200 WP should be followed.
\end{abstract}

\section{KEYWORDS}

provax, chickpea, seed treatment, jashore, fungicide.

\section{INTRODUCTION}

Pulses are the leguminous crops which added additional nitrogen to the soil from atmosphere. It plays a vital importance in the daily diet of Bangladeshi people and also in commercial agricultural market of Bangladesh (Kobir et. al., 2019). Moreover, it also improves the quality of soil so far. In Bangladesh a total of 0.937 million metric ton pulses were grown from 0.78 million ha of land in the fiscal year of 2018-2019 (AIS, 2020). Due to lack of production of pulses per capita availability of pulses of Bangladeshi people is also low (Azad et al., 2019). Chickpea is one of the major pulse crops in Bangladesh. This pulse crop is act as a unique one cause it contains almost $40 \%$ protein of its individual weight, in addition now-a-days human diseases like heart failure, cancer, diabetes etc. is on alarming phase and chickpea has potential to reduce these type of human diseases (Merga and Haji, 2019). In the last year about 0.005 million metric ton chickpea was produced from 0.004 million ha of land in Bangladesh (AIS, 2020). The average yield of chickpea in Bangladesh is 1.19 ton per hectare whereas average global yield is about 1.8 ton per hectare (Merga and Haji, 2019).

Low productivity of this promising pulse crop is attributed by different biotic and abiotic stresses. The most limiting factors among the biotic factors are foot and rootrot, fusarium wilt, ascochyta blight, cutworm and pod borer (Smithson et al., 2009). Among the biotic stresses a number of seed-borne and soil-borne diseases like foot and rootrot, Fusarium wilt play a vital role in limiting the yield of chickpea which is caused by Sclerotium rolfsii and Fusarium oxysporium, respectively (Azad et al., 2019). Both externally and internally seeds are acts as a host of wide range of microorganisms (Utobo et al., 2011). These microorganisms affect seedling vigor, reduce seed germination and ultimately develop abnormal seedlings (Khanzada et al., 2002; Islam and Monjil, 2016). The basic principle involved in the control of a seed-borne disease is reducing the population of primary inoculum of the pathogen. Infected seeds are one of the most important sources of primary inoculum that survives between cropping seasons (Malaker and Mian, 2009). Seed treatment refers to the application of certain agents like physical, chemical or biological to the seed prior to sowing in order to suppress, control or repel pathogens, insects and other pests that attack seeds, seedlings or plants and it ranges from a basic dressing to coating and pelleting (Sharma et al., 2015). Seed treatments helped to improve the yields of many different crops by providing the protection from pre and post-emergent insects and diseases with insuring a uniform stand across a wide variety of soil types, cultural practices and environmental conditions (Crop Life Foundation, 2013). Seed treatment with fungicides improves plants stand, reduce as well as controls seed-borne diseases, improves seedling vigor and crop yield 
(Tanweer, 1982; Shah and Jain, 1993; Klich et al., 1994). Seedling disease causing pathogens that reside in soil and in seed surface or inside the seed can be controlled successfully by seed treatment with fungicides (Rokib and Monjil, 2017).

Time to time pesticide companies are introducing different fungicides in the local market to combat these types of soil-borne and seed-borne diseases by seed treatment as well as by spraying. BARI Chola-10 is a recently released variety of Bangladesh Agricultural Research Institute and hence there is no record of its expression over soil-borne and seedborne diseases as well as grain yield when the seeds are treated with new or existing fungicides that are available in local market. Chickpea is a cool season crop but recently climate and weather of the world has becoming extreme, thus pathogens are getting favorable atmosphere for survival and multiplication and for this reason production of chickpea in Bangladesh is decreasing day by day, hence it is badly needed to cope up with these pathogens by applying different techniques (Devasirvatham and Daniel, 2018). So this experiment was undertaken to increase the productivity of BARI Chola-10 in changing climate of Jashore region.

\section{Materials ANd METHODS}

\subsection{Experimental site}

The research was conducted at the pulses research lab and pulses research field in Regional Agricultural Research Station, Jashore, Bangladesh during the rabi season of 2019-2020. The experimental site is located on $23^{\circ} 18^{\prime}$ latitude and $89^{\circ} 18^{\prime}$ longitude with an elevation of $19 \mathrm{~m}$ from sea level (Kobir et al., 2020). The location is under the Agro Ecological Zone (AEZ11) namely 'High Ganges River Floodplain’ (BBS, 2019).

\subsection{Experiment on laboratory condition}

\subsubsection{Collection of working samples}

One high yielding variety BARI Chola-10 was used in this experiment. The variety was collected from Regional Agricultural Research Station, Jashore. Five fungicides namely Provax 200 WP (Carboxin +Thiram), Secure 600 WG (Fenamidone + Mancozeb), Rovral 50 WP (Iprodione), Bavistin 50 WP (Carbendazim) and Captan 50 WP were collected from local market of Jashore.

\subsubsection{Preparation of working sample}

Six conical flasks of $250 \mathrm{ml}$ were filled with $100 \mathrm{~g}$ seed of BARI Chola-10. After addition of adequate water in each conical flask it was kept overnight for imbibition. Then $250 \mathrm{mg}$ of each fungicide along with $100 \mathrm{~g}$ seeds was taken separately in $250 \mathrm{ml}$ conical flasks. With the addition of water drop by drop flasks were shaken manually for 10-15 minutes for proper coating of the fungicides.

\subsubsection{Experimental treatment and design}

The experiment was conducted in completely randomized design with three replications where seeds treated with five different fungicidal groups namely, Provax 200 WP (Carboxin +Thiram), Secure 600 WG (Fenamidone + Mancozeb), Rovral 50 WP (Iprodione), Bavistin 50 WP (Carbendazim), Captan 50 WP along with control were applied as treatments.

\subsubsection{Germination and seedling vigor test in petri dish}

Twenty-five seeds were randomly selected from each treatment for each replication. The seeds were placed on water soaked three folds blotter paper in glass petri dishes. Two petri dishes were taken for each replication for placement of the seeds. Out of the two petri dishes twelve seeds were plated in one and another thirteen seeds were plated in another dish at equal distance. The seeds were incubated at $25 \pm 2^{\circ} \mathrm{C}$.

\subsubsection{Collection of data and analyzing statistically}

After 10 days of incubation, numbers of seeds sprouted were counted and the data were expressed as percentage according to the following formula:

$$
\text { Germination }(\%)=\frac{\text { Number of sprouted seeds }(2 \mathrm{~mm} \text { radicle })}{\text { Total number of seeds tested }} \times 100
$$

After then plumule and radicle length were measured by mm scale and these data were used to calculate vigor index according to a study (Abdul Bakshi and Anderson, 1973):

Vigor index $=$ Germination (\%) $\times($ Radicle length + Plumule length $)$

All the data then tabulated and analyzed statistically by using a software statistix-10 and means were compared by least significance difference at alpha $\leq 0.05$.

\subsection{Experiment in field condition}

\subsubsection{Soil}

The experimental field was a medium high land with sandy clay loam soil texture having $1.5 \%$ organic matter and the soil is slightly alkaline in nature. The experimental site belongs to "Calcareous Dark-gray Floodplain Soil". The physico-chemical properties of the soil have been presented in (Table 1).

\begin{tabular}{|c|c|c|c|c|c|c|c|}
\hline \multicolumn{8}{|c|}{ Table 1: soil properties of the experimental field } \\
\hline \multirow{2}{*}{$\begin{array}{c}\text { Soil } \\
\text { depth } \\
\text { (cm) }\end{array}$} & \multicolumn{3}{|c|}{$\begin{array}{l}\text { Particle size } \\
\text { distribution }\end{array}$} & \multirow{2}{*}{$\begin{array}{c}\text { Textural } \\
\text { class }\end{array}$} & \multirow{2}{*}{$\begin{array}{c}\text { Bulk } \\
\text { density } \\
\left(\mathrm{g} \mathrm{cm}^{-3}\right)\end{array}$} & \multirow[t]{2}{*}{$\mathrm{pH}$} & \multirow{2}{*}{$\begin{array}{c}\text { Soil } \\
\text { Organic } \\
\text { Matter } \\
(\%)\end{array}$} \\
\hline & $\begin{array}{c}\text { Sand } \\
(\%)\end{array}$ & $\begin{array}{l}\text { Silt } \\
(\%)\end{array}$ & $\begin{array}{l}\text { Clay } \\
(\%)\end{array}$ & & & & \\
\hline $0-15$ & 53.00 & 24.28 & 22.72 & $\begin{array}{c}\text { Sandy clay } \\
\text { loam }\end{array}$ & 1.42 & 7.3 & 1.5 \\
\hline
\end{tabular}

Source: Soil science division, Bangladesh Agricultural Research Institute

\subsubsection{Climate}

The climate of the experimental site is subtropical monsoon in nature with adequate rainfall during May to October and dearth rainfall during November to April. Yearly average rainfall is about $1600 \mathrm{~mm}$ and in addition about $90 \%$ of the total rainfall occurs from May to October which is uneven and unpredictable in nature. Monthly average temperature ranges from $20^{\circ} \mathrm{C}$ in January to $35^{\circ} \mathrm{C}$ in April. Weather information regarding precipitation, temperature, relative humidity at the experimental site during the period of study has been presented in (Figure 1).



Figure 1: Weather data of Jashore from November 2019- May 2020 (Source: Weather station, RARS, Jashore)

\subsubsection{Planting material}

BARI Chola-10 was used as planting material in this experiment. The planting material was collected from pulses seed cold storage of Regional Agricultural Research Station, Jashore. BARI Chola-10 is an erect type variety which is tolerant to drought, heat and botrytis gray mold disease. It usually completes its life cycle in between 112-121 days and average grain yield is $1800-2030 \mathrm{~kg} \mathrm{ha}^{-1}$ (Azad et al., 2019).

\subsubsection{Experimental treatment and design}

In research field the experiment was conducted in randomized completely block design with three replications where there were six fungicidal groups as a treatment viz., Provax 200 WP (Carboxin +Thiram), Secure 600 WG (Fenamidone + Mancozeb), Rovral 50 WP (Iprodione), Bavistin 50 WP (Carbendazim), Captan 50 WP and control. Thus, total number of plots was 18. Five different fungicides @2.5 g kg-1 seeds of BARI Chola-10 were taken in five different pots. After that sterilized water was added in these pots drop by drop which was thoroughly mixed with seeds and fungicides. Then seeds were kept for several minutes to become dry until the fungicides did not clot with the seeds. 


\subsubsection{Crop husbandry}

At first the land was ploughed four times by a tractor drawn cultivator. Then treated seeds were sown @35 kg ha-1 where plant to plant distance of $15 \mathrm{~cm}$ and line to line distance of $30 \mathrm{~cm}$ was maintained. Fertilizers were applied @20:40:20:10 NPKS kg ha-1 respectively. All the fertilizers were applied as basal during final land preparation. Two times weeding was done at 35 days after sowing and 68 days after sowing. Crops were harvested at proper maturity stage. After harvesting crops were dried in sun and after that dried crops were threshed by power tiller drawn thresher.

\subsubsection{Collection of experimental data and analyzing statistically}

Days to $50 \%$ flowering, days to mature, disease incidence (\%) at @30 days after sowing, plant height in $\mathrm{cm}$ at harvest, plants $\mathrm{m}^{-2}$ at harvest, pods plant ${ }^{-1}$ at harvest, grain yield $\left(\mathrm{kg} \mathrm{ha}^{-1}\right)$ were recorded. Disease incidence was calculated according to the following formula (Harun-Or-Rashid et al., 2019):

$$
\text { Disease Incidence }(\%)=\frac{\text { Number of infected plants }}{\text { Total Number of plants }} \times 100
$$

Then collected data were tabulated in Microsoft excel and a statistical software statistix- 10 was used to calculate analysis of variance and means of the measured parameters were compared using LSD at alpha $\leq 0.05$.

\section{RESULTS}

\subsection{Laboratory parameters}

\subsubsection{Effect on germination}

Fungicide treatments showed significant variation for the parameter germination (\%). The highest (92\%) germination was found in Provax 200 WP fungicide application which is statistically similar to Secure 600 WG and Rovral 50 WP application as seed treating chemical. The lowest $(67.67 \%)$ germination was recorded in control treatment (Table 2).

\subsubsection{Effect on germination increment over control}

Different fungicidal group which was used as seed treating agent effect on germination (\%) comparing to control treatment. The highest positive variation $(36 \%)$ in germination over control was recorded in seed treatment with provax $200 \mathrm{WP}$ and the lowest positive increment of germination $(9 \%)$ over control was observed in seed treatment with Captan50 WP (Figure 2).

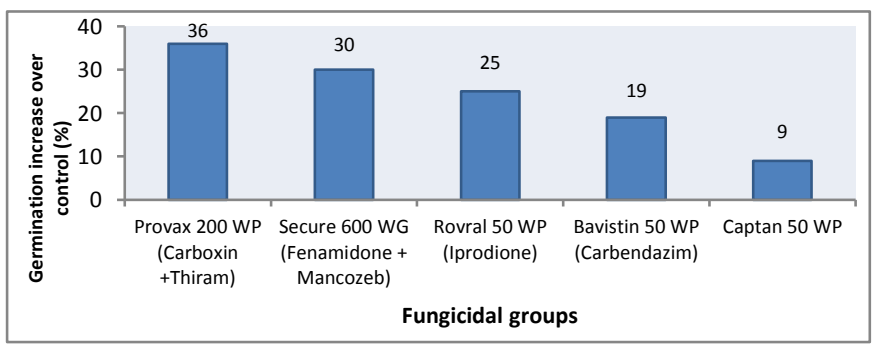

Figure 2: Percent germination increment over control

\subsubsection{Effect on plumule length}

Fungicidal seed treatments showed significant variation for the parameter plumule length. The highest (31.22 $\mathrm{mm}$ ) plumule length was found in seed treatment with Provax 200 WP which is followed by seed treatment with Secure $600 \mathrm{WG}$ and Rovral $50 \mathrm{WP}$. The lowest $(9.2 \mathrm{~mm})$ plumule length was observed in control treatment (Table 2).

\subsubsection{Effect on radicle length}

Seed treatments showed significant variation for the parameter radicle length. The highest $(12.26 \mathrm{~mm}$ ) radicle length was found in seed treatment with Provax 200 WP which is statistically similar to seed treatment with to Secure 600 WG, Rovral 50 WP and Bavistin 50 WP. The lowest (2.89 $\mathrm{mm}$ ) radicle length was observed in control treatment (Table 2).

\subsubsection{Effect on vigor index}

Seed treatments with different fungicidal group showed significant variation for the parameter vigor index. The highest vigor index (4015.5) was observed in seed treatment with Provax 200 WP which is followed by seed treatment with to Secure 600 WG, Rovral 50 WP and Bavistin 50 WP. The lowest vigor index (812.7) was observed in control treatment (Table 2).

\begin{tabular}{|c|c|c|c|c|c|}
\hline Treatments & 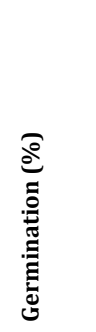 & 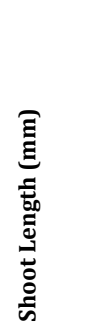 & 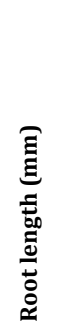 & 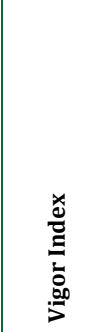 & 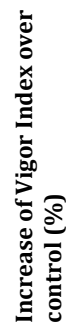 \\
\hline $\begin{array}{l}\text { Provax } 200 \text { WP (Carboxin } \\
+ \text { Thiram) }\end{array}$ & $92 \mathrm{a}$ & $31.22 \mathrm{a}$ & $12.26 \mathrm{a}$ & $4015.5 \mathrm{a}$ & 395 \\
\hline $\begin{array}{l}\text { Secure } 600 \text { WG (Fenamidone } \\
+ \text { Mancozeb) }\end{array}$ & $88 a b$ & $22.14 \mathrm{~b}$ & 9.11ab & $2755.9 \mathrm{~b}$ & 240 \\
\hline Rovral 50 WP (Iprodione) & $84.67 \mathrm{ab}$ & $18.32 \mathrm{~b}$ & $9.47 \mathrm{ab}$ & $2349 \mathrm{bc}$ & 189 \\
\hline Bavistin 50 WP (Carbendazim) & $80.67 \mathrm{bc}$ & $22.65 \mathrm{~b}$ & $9.17 \mathrm{ab}$ & $2573.5 b c$ & 217 \\
\hline Captan 50 WP & $74 \mathrm{~cd}$ & $18.37 \mathrm{c}$ & $6.28 \mathrm{bc}$ & $1833.2 \mathrm{c}$ & 126 \\
\hline Control & $67.67 d$ & $9.2 \mathrm{~d}$ & $2.89 \mathrm{c}$ & $812.7 \mathrm{~d}$ & - \\
\hline CV (\%) & 5.56 & 16.73 & 27.69 & 17.96 & \\
\hline $\operatorname{LSD}(\mathrm{p} \leq 0.05)$ & 8.02 & 6.04 & $4 . .04$ & 763.54 & \\
\hline
\end{tabular}

LSD = least significant difference; $\mathrm{CV}=$ coefficient of variation; means followed by the same letter did not show significant difference at $p \leq 0.05$ according to least significant difference.

\subsubsection{Effect on vigor index increment over control}

The highest increment of vigor index over control (395\%) was recorded in seed treatment with Provax 200 WP which is followed by Secure 600 WG and Rovral 50 WP treatment. The lowest (126\%) increment of vigor index over control was found in seed treatment with Captan 50 WP (Table 2).

\subsection{Field parameters}

\subsubsection{Effect on disease incidence}

Fungicides caused notable impact on the percent incidence of soil-borne and seed-borne diseases (wilt, rot etc.) on selected Chickpea variety BARI Chola-10 (Figure 3). Variation in the fungicides posed a significant difference on disease incidence. The highest disease infection found in control treatment (20.22\%). Among the fungicide treatments, highest disease infection occurred in case of Captan 50 WP (15.63\%) followed by Rovral 50 WP (12.77\%), Bavistin 50 WP (11.72\%) and Secure 600 WG (6.7\%). The lowest disease found in Provax 200 WP (3.33\%).

\subsubsection{Effect on percent disease reduction over control treatment}

Fungicides significantly reduced percent disease incidence over control treatment (Figure 4). Among the fungicide treatments, highest disease reduction occurred in Provax 200 WP (84\%) followed by Secure 600 WG (67\%), Bavistin 50 WP (42\%) and Rovral 50 WP (37\%). The fungicide Captan 50 WP (23\%) got the lowest disease reduction.



Means followed by the same letter did not show significant difference at $\mathrm{p} \leq 0.05$ according to least significant difference

Figure 3: Effect of fungicides on disease incidence (\%) 


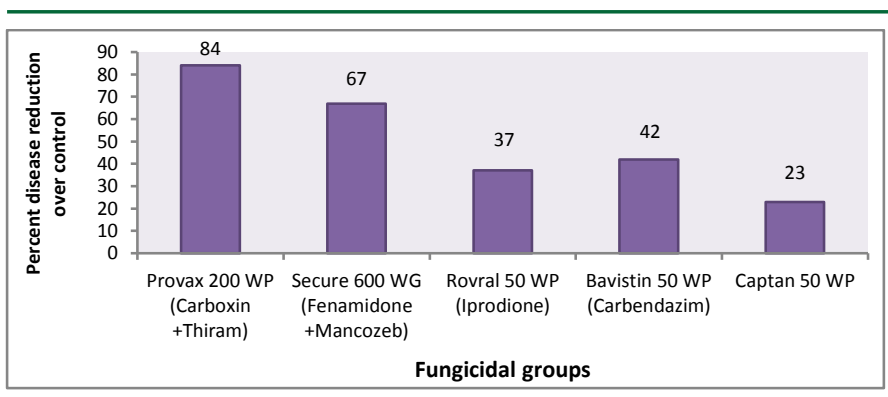

Figure 4: Effect of fungicides on percent disease reduction over control

\subsubsection{Effect on days to 50\% flowering}

Fungicidal groups used for seed treatment showed significant variation in case of parameter days to $50 \%$ flowering. The longest days (67) was observed in control plot and on the other hand the shortest (65) days was required to attain $50 \%$ flowering was observed when seeds were treated by Provax 200 WP (Table 3).

\subsubsection{Effect on days to mature}

Different fungicidal group did not show significant variation for days to mature (Table 3).

\subsubsection{Effect on plant height}

The highest plant height $(63.67 \mathrm{~cm})$ was recorded when seeds were treated with Provax 200 WP which is statistically similar to treatment with Secure $600 \mathrm{WG}$ and the lowest plant height $(40 \mathrm{~cm})$ was revealed by control plot (Table 3).

\subsubsection{Effect on plants $\mathrm{m}^{-2}$}

Different treatments showed significant variation for plants $\mathrm{m}^{-2}$. The highest (31) plants $\mathrm{m}^{-2}$ was found by seed treatment with Provax $200 \mathrm{WP}$ which is statistically similar to Secure 600 WG. On the other hand, the lowest plants $\mathrm{m}^{-2}$ (18.) was observed in control plot (Table 3 ).

Table 3: Field performance of different seed treating fungicidal group in yield and yield contributing characters of chickpea

\begin{tabular}{|c|c|c|c|c|c|c|}
\hline Treatments & 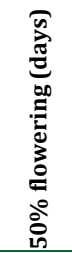 & 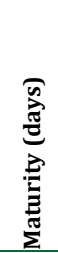 & 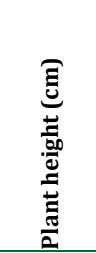 & 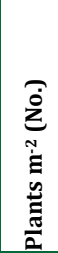 & 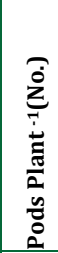 & 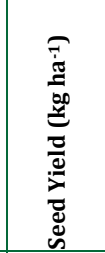 \\
\hline $\begin{array}{c}\text { Provax } 200 \text { WP (Carboxin } \\
\text { +Thiram) }\end{array}$ & $65 c$ & 112 & $63.67 a$ & $31 a$ & $81 a$ & 2062.7a \\
\hline $\begin{array}{c}\text { Secure } 600 \text { WG (Fenamidone } \\
+ \text { Mancozeb) }\end{array}$ & $65 b c$ & 112 & $54.67 \mathrm{~b}$ & $28 \mathrm{ab}$ & $76 a b$ & 1861.3ab \\
\hline Rovral 50 WP (Iprodione) & $65 b c$ & 113 & $52.33 \mathrm{bc}$ & $26 \mathrm{bc}$ & $72 \mathrm{bc}$ & 1828.3ab \\
\hline Bavistin 50 WP (Carbendazim) & 66abc & 112 & $50.67 \mathrm{bc}$ & $26 \mathrm{bc}$ & $71 \mathrm{bc}$ & $1659 \mathrm{bc}$ \\
\hline Captan $50 \mathrm{WP}$ & $66 \mathrm{ab}$ & 113 & $47.33 \mathrm{c}$ & $23 \mathrm{~cd}$ & $68 \mathrm{c}$ & $1453 \mathrm{~cd}$ \\
\hline Control & $67 a$ & 113 & $40 \mathrm{~d}$ & $18 d$ & $58 d$ & $1283.3 \mathrm{~d}$ \\
\hline $\mathrm{CV}(\%)$ & 0.92 & 0.58 & 5.41 & 9.6 & 4.43 & 8.92 \\
\hline $\operatorname{LSD}(p \leq 0.05)$ & 1.1 & NS & 5.06 & 4.41 & 5.72 & 274.49 \\
\hline
\end{tabular}

LSD = least significant difference; $\mathrm{CV}=$ coefficient of variation; means followed by the same letter did not show significant difference at $p \leq 0.05$ according to least significant difference.

\subsubsection{Effect on pods plant ${ }^{-1}$}

Different treatments showed significant variation for pods plant ${ }^{-1}$. The highest (81) pods plant ${ }^{-1}$ was found by seed treatment with Provax 200 WP which is statistically similar to Secure 600 WG. On the other hand the lowest pods plant ${ }^{-1}$ (58) was observed in control plot (Table 03).

\subsubsection{Effect on grain yield}

Grain yield revealed that it is statistically significant due to different fungicidal group as seed treating agent. The highest grain yield $(2062.7 \mathrm{~kg}$ $\mathrm{ha}^{-1}$ ) was observed when seeds were treated by fungicide Provax $200 \mathrm{WP}$ (Carboxin+ Thiram) which is followed by $\left(1861.3 \mathrm{~kg} \mathrm{ha}^{-1}\right)$ and $1828.3(\mathrm{~kg}$ ha $^{-1}$ ) when seeds were treated by Secure 600 WG (Fenamidone +Mancozeb) and Rovral 50 WP(Iprodione), respectively. On the other hand the lowest grain yield (1283.3 $\left.\mathrm{kg} \mathrm{ha}^{-1}\right)$ was found by control treatment (Table 3).

\subsection{Correlation co-efficient and regression equation}

Different yield contributing characters have strong correlation with grain yield of chickpea. Vigor index ( $\mathrm{r}=0.94)$ (Figure 5), plant height $(\mathrm{cm})$ $(\mathrm{r}=0.97)$, plants $\mathrm{m}^{-2}(\mathrm{r}=0.97)$ and pods plant ${ }^{-1}(\mathrm{r}=0.96)$ have strong positive correlation with grain yield of chickpea (Table 4).

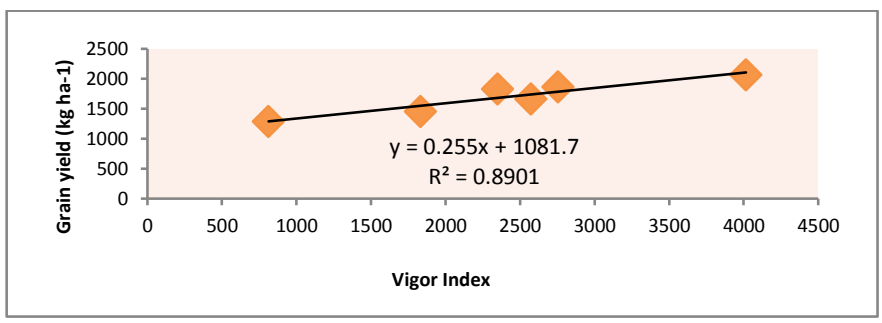

Figure 5: Correlation co-efficient of vigor index VS grain yield (kg ha-1)

\begin{tabular}{|c|c|c|c|}
\hline \multirow[b]{2}{*}{ Parameters } & \multicolumn{2}{|c|}{$\begin{array}{l}\text { Correlation-co- } \\
\text { coefficient }\end{array}$} & \multirow[b]{2}{*}{$\begin{array}{l}\text { Regression } \\
\text { equation }\end{array}$} \\
\hline & $R^{2}$ value & $\mathrm{R}$ value & \\
\hline $\begin{array}{l}\text { Days to } 50 \% \text { flower VS } \\
\text { Grain yield (kg ha-1) }\end{array}$ & 0.991 & -1.00 & $Y=-388.5 x+27206$ \\
\hline $\begin{array}{l}\text { Days to mature VS Grain } \\
\text { yield }\left(\mathrm{kg} \mathrm{ha}^{-1}\right)\end{array}$ & 0.67 & -0.82 & $Y=-711.5 x+81822$ \\
\hline $\begin{array}{l}\text { Plant height }(\mathrm{cm}) \text { VS Grain } \\
\text { yield }\left(\mathrm{kg} \mathrm{ha}^{-1}\right)\end{array}$ & 0.935 & 0.97 & $\mathrm{Y}=35.20 \mathrm{x}-120$ \\
\hline $\begin{array}{l}\text { Plants m-2 VS Grain yield } \\
\left(\mathrm{kg} \mathrm{ha}^{-1}\right)\end{array}$ & 0.938 & 0.97 & $\mathrm{Y}=63.34 \mathrm{x}+90.10$ \\
\hline $\begin{array}{l}\text { Pods plant }{ }^{-1} \text { VS Grain yield } \\
\left(\mathrm{kg} \mathrm{ha}^{-1}\right)\end{array}$ & 0.92 & 0.96 & $Y=35.40 x-822.3$ \\
\hline
\end{tabular}

On the other hand days to $50 \%$ flowering ( $r=-1.00$ ) (Table 4), days to maturity ( $\mathrm{r}=-0.82)$ (Table 4) and disease incidence (\%) ( $\mathrm{r}=-0.95)$ (Figure 6 ) have strong negative correlation with grain yield of chickpea.

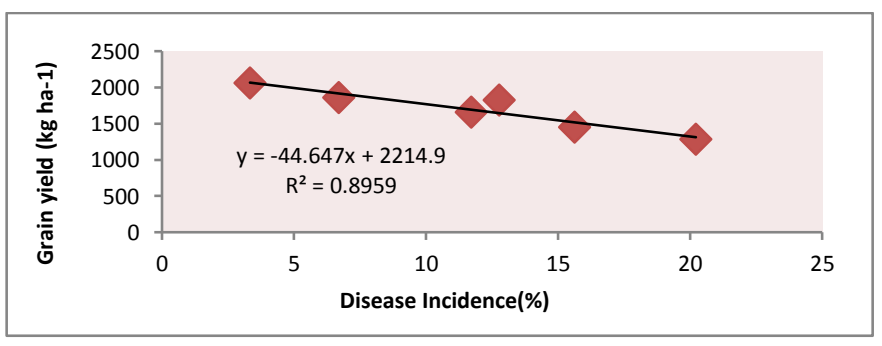

Figure 6: Correlation co-efficient of disease Incidence (\%) VS grain yield $\left(\mathrm{kg} \mathrm{ha}^{-1}\right)$

\section{Discussions}

A group researcher had conducted an experiment in cowpea and they stated that highest germination was observed when seeds were treated with Provax 200 WP (Rahman et al., 2012). Some researcher revealed that seeds treated with Secure 600 WG increased germination and then followed by seed treatment with Provax 200 WP (Morshed et al., 2014). In present study highest seed germination was found when seeds were treated with Provax 200 WP which is statistically similar to seed treatment with Secure $600 \mathrm{WG}$ and this is as par with the past study so far. May be the reason behind that result is seed treatment with fungicide, biocide and 
leaf extract enhance seed germination and enhance seedling vigor also, stated by (Chowdhari et al., 2013).

Rokib and Monjil revealed that seed treatment with Secure 600 WG results in highest shoot length in lentil which is followed by Dithane M-45 (Rokib and Monjil, 2017). Similar result also found by in chickpea (Morshed et al., 2014). They expressed that maximum shoot length over control (11.78\%) was found when seeds were treated with Secure 600 WG. In case of root length over control they found maximum value $(21.80 \%)$ when seeds were treated with Provax 200 WP. In the recent study maximum plumule length was recorded in case of seed treatment with Provax 200 WP followed by Secure 600 WG and maximum radical length was observed when seeds were treated with Provax 200 WP which is more or less similar to the past literature which has mentioned before and this is may be for fungicides and bio-control agent plays important role in growth and yield enhancement in lentil, revealed by (Kumari et al., 2018).

(Carbendazim + Thiram) as seed treating fungicide was proved the best in plant height enhancement in lentil compared to alone and in our present study (Carboxin + Thiram) gives best performance in plant height (Kumari et al., 2018). Highest number of pods plant ${ }^{-1}$ was found when seeds were treated with Provax $200 \mathrm{WP}$ which is as par with expressed that highest mortality of plants for soil born disease was observed in control plot where no seed treatment was applied (Shahiduzzaman, 2015). He also found that maximum and significant disease reduction over control was achieved where seeds treated with Provax 200 WP.

Maximum disease incidence was recorded in control plot and minimum was recorded while Apron Star and Mancozeb were applied as seed treating agent, respectively found (Mengist et al., 2018). Some researchers found that fungicides treated chickpea plots expressed about $30 \%$ disease incidence where control plot expressed $80 \%$ disease incidence (Landa et al., 2014). A scientist revealed that seed treatment with fungicides in chickpea not only suppress the pathogen activity but also increased grain yield and it was almost double than the control plot (Kamdi et al., 2012; Subhani et al., 2011; Yigitoglu, 2006; Landa et al., 2014). In the recent study highest disease incidence was observed in control treatment whereas lowest disease incidence and highest disease incidence reduction over control was observed where seeds were treated with Provax $200 \mathrm{WP}$ and the highest grain yield was also recorded where seeds were treated with Provax 200 WP which is supported by previous study that had been reviewed above.

\section{CONCLUSION}

Growth performance and grain yield both are hampered due to some devastating soil-borne and seed-borne disease of chickpea like foot and root rot, wilting etc. But seed treatment by fungicides can reduce the problem so far. Provax 200 WP (Carboxin +Thiram), Secure 600 WG (Fenamidone + Mancozeb), Rovral 50 WP (Iprodione), Bavistin 50 WP (Carbendazim), Captan 50 WP are the seed treating fungicides that had been tested in this experiment. The highest germination, plumule length, radicle length, vigor index, percent disease reduction over control, plant height, plants $\mathrm{m}^{-2}$, pods plant ${ }^{-1}$, grain yield and the lowest days to $50 \%$ flowering, disease incidence was found when seeds were treated with fungicide Provax 200 WP (Carboxin +Thiram). So to mitigate soil-borne and seed-borne diseases as well as to increase seed yield in chickpea seed treatment with Provax 200 WP (Carboxin +Thiram) may be followed.

\section{ACKNOWLEDGMENT}

The experiment was financially assisted by Regional Agricultural Research Station, Jashore. The authors express their cordial gratitude to the colleagues and staffs of Regional Agricultural Research Station, Jashore, Bangladesh.

\section{REFERENCES}

Abdul-Bakshi, A.A., Ander, S.J.D., 1973. Vigour determination of soybean seeds by multiple criteria. Crop Science., 13, Pp. 630-632.

AIS. 2020. Agricultural Information Services. Department of Agricultural Extension, Bangladesh. Production and area of field crops, Pp. 14.
Azad, A.K., Wahab, A., Saha, M.G., Nesa, Z., Rahman, M.L.,Rahman, H.H., Amin, L., 2019. Krishi Projukti Hatboi (Handbook on Agro-technology), $8^{\text {th }}$ edition. Bangladesh Agricultural Research Institute, Gazipur-1701, Bangladesh, 47, 64, 67.http://www.bari.gov.bd

BBS. 2019. Bangladesh Bureua of Statistics. Yearbook of agricultural statistics-2018,p.

08.http://bbs.portal.gov.bd/sites/default/files/files/bbs.portal.gov.bd /page/1b1eb817_9325_4354_a756_3d18412203e2/Yearbook-2017Final-05-05-2018.pdf

Chowdhary, C.S., Jain, S.C., Kumar, R., Chowdhary, J.S. 2013. Efficacy of different fungicides, biocides and botanical extract seed treatment for controlling seed-borne colletotrichum sp. In chilli (capsicum annuum l.). The bioscan, 8 (1), Pp. 123-126.

Crop Life Foundation. 2013. The role of modern seedtreatment in U.S. crop production: A review of benefits.pp.-72. Retrieved from http://www. c roplifeame ri c a .org/ s i t e s /d e fau lt / fi l e s /SeedTreatment.pdf

Devasirvatham, V., Daniel, K.Y.T., 2018. Impact of high temperature and drought stresses on chickpea production. Agronomy, 8 (8), Pp. 145.

Harun-Or-Rashid, M., Meah, M. B., Uddin, M. I., Ahmed, S., Kashem, M.A., 2019. Gamma Radiated Wheat for Combating Devastating Blast Disease (MagnaportheOryzaeTriticum) In Bangladesh. Agricultural Science, 1 (1), Pp. 1. https://doi.org/10.30560/as.v1n1p1

Islam, M.S., Monjil, M.S., 2016. Effect of seed washing either alone or in combination with garlic extract and Knowin 50WP on quality of jute seeds. Asian J. Med. Biol. Res., 2, Pp. 318-323.

Kamdi, D.R., Mondhe, M.K., Jadesha, G., Kshirsagar, D.N., and Takur, K.D., 2012. "Efficacy of botanicals, bio-agents and fungicides against Fusariumoxysporum f. sp. ciceris, in chickpea wilt sick plot." Annals of Biological Research, 11, Pp. 5390- 5392.

Khanzada, K.A., Rajput, M.A., Shah, G.S., Lodhi, A.M., and Mehboob, F., 2002. Effect of seed dressing fungicides for the control of wheat roots. Appl. Soil. Ecol., 13, Pp. 271-282.

Klich, M.A., Arthur, K.S., Lax, A.L., Blade, J.M., 1994. A potential new fungicide for stored grains. Mycopathol., 127, Pp. 123-127.

Kobir, M.S., Paul, S., Harun-Or-Rashid, M., 2019. Efficacy of locally available plant seed oils against pulse beetle infesting blackgram. Journal of Bioscience and Agriculture Research, 22 (01), Pp. 1823-1828. https://doi.org/10.18801/jbar.220119.224

Kobir, M.S., Rashid, M.H., Ahmed, S., 2020. Development of Integrated Fertilizer Management Strategies in Lentil for Higher Productivity in the South-Western Region of Bangladesh. Agricultural science., 2 (1), Pp. 275-281.https://doi.org/10.30560/as.v2n1p275

Kumari, R., Ashraf, S., Bagri, G.K., Khatik, S.K., Bagri, G.K., Bagdi, D.L., 2018. Impact of seed treatment from bio-agents and fungicides on growth, biomass and yield of lentil (Lens culinaris Medik). Journal of Pharmacognosy and Phytochemistry., 7 (3), Pp. 251-253.

Landa, B.B., Navas-Cortes, J.A., Jimenez-Diaz, R.M., 2014. Integrated management of Fusarium wilt of chickpea with host resistance, biological control and seed dressing fungicides. Phytopathology, 94, Pp. 946-960.

Malaker, P., Mian, I., 2009. Effect of seed treatment and foliar spray with fungicides in controlling black point disease of wheat. Bangladesh Journal of Agricultural Research, 34 (3), Pp. 425-434. https://doi.org/10.3329/bjar.v34i3.3968

Mengist, Y., Sahile, S., Sintayehu, A., Singh, S., 2018. Evaluation of Chickpea Varieties and Fungicides for the Management of Chickpea Fusarium Wilt Disease (Fusariumoxysporumf.sp. ciceris) at Adet Sick Plot in Northwest Ethiopia. International Journal of Agronomy, 2018, Article ID 6015205, 7 pages https://doi.org/10.1155/2018/6015205.

Merga, B., Haji, J., 2019. Economic importance of chickpea: Production, value, and world trade, Cogent Food \& Agriculture, 5 (1), Pp. 1615718. https://doi.org/10.1080/23311932.2019.1615718 
Morshed, M.G., Kashem, M.A., Hossain, I., Rafi, M.Y., and Latif, M.A., 2014. Effect of fungicides in controlling root rot (Fusariumsolani) of chick pea. Life Science J., 11, Pp. 99-102.

Rahman, Z., Haque, A.H.M.M., Zaman, M.A., Amin, M.F., Das, A.K., 2012. Efficacy of two fungicides and two botanicals to control foot and root rot disease (Sclerotiumrolfsii) of cowpea. Bangladesh J. Plant Pathol., 28, Pp. 29-32.

Rokib, A., Monjil, S.J., 2017. Fungicidal seed treatment on germination and seedling vigour of lentil var. BINA Masur-3. Asian J. Med. Biol. Res., 3 (1), Pp. 140-144.doi: 10.3329/ajmbr.v3i1.32050

Shah, R., Jain, J.P., 1993. Seed mycoflora of mustard and its control. Indian J. Mycol., 23, Pp. 291-295.

Shahiduzzaman, M., 2015. Efficacy of fungicides and botanicals in controlling foot and root rot of lentil. Bangladesh. J. Agril.Res., 40 (4), Pp. 711-715.

Sharma, K.K., Singh, U.S., Sharma, P., Kumar, A., Sharma, L., 2015. Seed treatments for sustainable agriculture-A review. Journal of Applied and $\begin{array}{lllll}\text { Natural } & \text { Science, } & 7 & \text { (1), } & \text { Pp. }\end{array}$ https://doi.org/10.31018/jans.v7i1.641
Smithson, J.B., Thompson, J.A., Summerfield, R.J., 2009. Chickpea (Cicerarietinum L.)," in Grain Legume Crops, R. J. Summerfield and E. H. Roberts, Eds., Pp. 312-390, Collins, London, UK.

Subhani, M.N., Sahi, S.T., Hussain, S., Ali, A., Iqbal, J., Hameed, K., 2011. Evaluation of various fungicides for the control of gram wilt caused by Fusariumoxysporum f. sp. Ciceris. African Journal of Agricultural Research, 6 (19), Pp. 4555-4559.

Tanweer, A., 1982. Effect of new fungicide on viability of rice and sorghum seeds. Pestology, 6, Pp. 9-10.

Utobo, E.B., Ogbodo, E.N., Nwogbaga, A.C., 2011. Seed borne mycota associated with rice and their influence on growth of Abakaliki, Southeast agro-ecology, Nigeria. Libiyan Agric. Res. Cen. J. Inter., 2, Pp. 79-84.

Yigitoglu, D., 2006. Research on the effect of different fungicides on the yield and yield components of some chickpea (CicerarietinumL.) cultivars that treated in different fungicides in kahramanmaras region, $\mathrm{PhD}$ thesis, Department of Field Crops Institute of Natural and Applied Science University of Cukurova, Adana, Turkey

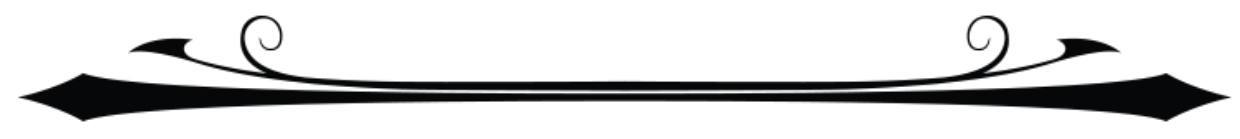

